\title{
IMPORTANCE OF THE IRISH DRAMATIC MOVEMENT
}

\author{
Yrd. Doç. Dr. Belgin ELBİR
}

The general revival of drama at the end of the nineteenth century was the result of something more than the usual conjunction of talent, intellectual climate, and social and economic factors. It came into existence by the determination of amateurs who could realize that diama was unaware of the great changes in men and things the century had witnessed.

In Britain, the seeds of this revival were scattered in London, in Glasgow, in Manchester, and most eftectively, in Dublin. Although Ireland had given to the English theatre some of its most distinguished playwrights such as Oscar Wilde and George Bernard Shaw, the theatre in Iraland had never been more than a poor relation of the English theatre. In 1898, under the leadership of William Buttler Yeats, Lady Augusta Gregory and Edward Martyn, an attempt was made to establish an Irish Literary Theatre. In his lecture delivered to the Royal Academy of Sweden on receiving the Nobel Prize, 'Yeats chose as his theme "the Irish Dramatic Movement" because he believed that the English committees would never have sent his name if he had written no plays, no dramatic criticism, or if his Iyric poetry had not a quality of speech practised upon the stage. About the Irish Dramatic Movement, he said that the great mass of the Irish people were accustomed to political speeches and read little, so from the very start they had felt that they needed a theatre of their own. It was not, however, until he met in 1896 Lady Gregory, a member of an old Galway family, that such a theatre had become possible.

After several years of experimentation with methods of writing and production, developing both dramatists and an acting company, a series of appearances in. London attracted the attention of the generous Miss. Horniman who supplied the funds for a small Dublin playhouse which she rebuilt and presented to the company Thus, the Abbey Theatie became the permanent home of this company. 
The Abbey was a unique establishment. First of all, its actors were mostly amateurs with no training in the professional theatre, and its playwrights were mainly literary figures, not dramatists whose experience had been totally confined to writing drama. Seconldly, in a period when the fashion was for realism, the Abbey was concerned with the creation of the folk-play. The reason for this was that the Irish National Theatre was only one part of a genera! literary, cultural and political renaissance intended to establish the Irish Heritage. As Yeats said, they were writing with the aim of producing the image around them:

A play should tell the people of their own life of poetry where every man can see his qwn image. To ennoble the man of the roads, write of the roads, or of the people of romance, or the great historical people't

Yeats's dramatization of the "life of poetry where every man van see his own image" may be more properly considered later with other attempts to establish a modern poetic drama. A modern poetic drama could only be created by men aware not only of the spirit of their times, but of the poetic sytle which had been developed to give expression to that spirit.

In the creation of poetic drama W.B. Yeats played a major role. The necessities of the Irish Renaissance drove him to thinking more precisely on the creation of drama whose effects would remain after the fall of the curtain. He wanted to create a drama which would move the hearts and minds of men' in such a way that they would leave the theatre with a new understanding of their nature and fate. The poetic drama should be a living, not a literary thing; and in Yeats's opinion living poetry could be found in thespeech of the Irish peasant and his fondness of the heroic end domestic in legend and daily life. The attempts to establish poetic drama in the theatre of the last two centuries had failed because the models were drawn from the past, or if the subject-matter was the reflection of contemporary life, the solutions were not modern. In other words, the solutions were in conflict with the spirit of the time. Yeats thought that the revitalizing of the poetic tradition was to be accomplished in three ways. The diction should be sensuous and musical, the structure should be the "marshalling of the Irish fragmentary beauties

1. W.B. Yeats, Plays and Controversies (London: 1923), p. 30. 
into great literature" as he put it; and the theme of this drama should be chosen to give Ireland a constantly artistic conscience.

In Yeats's opinion, the dramatist should picture life in action, with an unpreoccupied mind, as the musician pictured it in sound and the sculptor in form. An action, taken out of all other actions should be reduced to its simplest from, or at any rate to as simple a form as it could be brought to without the audience's losing the sense of its place in the world. Moreover, the characters involved in the action should be freed from everything that was not a part of that action.

On'May 8, 1899 the Irish Literary Theatre opened its first season. with Yeats's The Countess Cathleen. Irishmen protested against it as an insult to the faith and to Irish womanhood. But English reviewers wrote in favour if it.

The play is about a woman's sacrifice of her soul for starving. people. It is short and brief like most of Yeats's other plays; it is a one-act play with five short scenes. As characters we have Shemus, a peasant; and his wife, Mary; their sor Teigue; Aleel, a poet; The Countess Cathleen; her foster mother, Oona; and two Demons disguised as Merchants. There are also peasant, servant of Countess Cathleen, and Angelical beings. In the first scene we are in the room where Shemus and Teigue are talking. There is a fire in the room, and through the open door, the trees of a wood can be seen. The scene has the effect of a painting. We learn that these people are starving when Shemus comes in. Apparently, he has not been able to find any food.

Teigue

Shemus

Teigue

Shemus

Teigue
: Then you have brought no dinner.

: I sat among the beggars at the cross-roads, And held a hollow hand among the others.

While they are talking, they hear music.

$$
\text { Shemus }
$$

: Who's passing there?

And mocking us with music?3

2 W.B. Yeats, The Countess Cathleen (London: 1929), p. 12.

3 İbid. p. 14. 
Cathleen, Oona and Aleel enter the room. Cathleen realizes how poor and hungry these people are.

Cathleen

: So you are starving even in this wood,

Where I had thought I would find nothing changed. ${ }^{4}$

She gives them all the money she has. But that is not enough. So the family sell their souls to the two demons, disguised as merchants. Only Mary refuses to do so. The demons tell Shemus and his son to cry aloud at every house door that they buy men's souls: First Merchant: You've but to cry aloud at every cross-road, At every house door, that we buy men's souls. And give so good a price that all may live. In mirth and comfort till the famine's done, Because we are Christian men.

Shemus : Come, ler's away.

Teigue : I shall keep running till I've earned the price. ${ }^{5}$

The Countess, who is desperate to save the starving people, agrees to sell her own soul to the demon-merchants. It is a difficult decision to make but she feels she has to. The peasants protest that - her soul is too valuable to be sold, but she is determined. They kiss her dress in gratitude. She dies. Her farewell speech is a good example of poetic language:

Cathleen : Bend down your faces, Oona and Aleel, I gaze upon them as the swallow gazes Upon the nest under the eave, begore she wander the loud waters. Do not weep

Too great a while, for there is many a candle On the High Altar through one fall. Aleel, who sang abouth the dancers of the woods,

That know not the hard burden of the world, Having but breath in their kind bodies, farewell! And farewell: Oona, you who have played with me, And bore me in your arms about the house When I was but a child and therefore happy, Therefore happy, even like those that dance. The storm is in my hair and I must go. ${ }^{6}$

\footnotetext{
4 İbid., p. 17.

5 İbid., p. 31 .

6 İbid., p. 99.
} 
Like this play, Yeats's plays are more lyrical than they are dramatic. In The Countess Cathleen there is a crisis when Cathleen decides to giverher soul to Satan. All movement in the play is towards this end. The movement and the crisis are there to reveal emotion. Like all the drama of Yeats, this play is also a combination of spiritual, dramatic and poetic elements. The pattern is an extension of conventional verse. The progress in the play is from the inward to the outward, which creates a sensuous atmosphere. Symbolism in the play is the agency that makes the universality of the theme explicit. To take Yeats's play as the expression of personal lyrical states of mind would be only superficial reading. Although a sho1t play, The Countess Cathleen is concerned with a great theme: Cathleen's sacrifice of self. This fact is true of Yeats's other short plays. Yeats was not the first to use symbolism in drama, but he is distinguished by his deliberate, free and intricate use of it. In The Countess Cathleen, while Cathleen is a symbol of self-sacrifice, the other character; Shemus, his son and all the rest who sell their souls are symbols of people who, when in poverty, are forced to give up all their spiritual values by their own instincts and not by any force from the outside. The vitality of Yeats's all dramatic works is also present in this play. This is the vitality both of content and from. In Yeats, the subject for observation is the life of the soul and spiritual powers, and this is why the progress is from inward to outward, from unseen to seen. For Yeats, drama has to use symbolism and personification. In The Countess Cathleen we have the personification of the attractions of the devil. Yeats makes use of music and supernatural elements such as angelic figures which are a fact of the action. The important thing is the submission of a soul to the all-enveloping spritual mystery as in the case of Cathleen. In the combining of the elements of seen and unseen, of natural and supernatural, of human and divine, ,action' comes to have the force of symbol, or, as in The Countess Cathleen, symbol assumes the character of action. The world Yeats creates is not an unreal one but it is very different from the world we are accustomed to find in drama.

Yeats had a life to express, he was a poet, and he had a sense for dramatic form. For the continuity of drama and its connection with the main stream of poetic writing, his work seems much more important than that of either Synge and the "realist." 
We said that Yeats can be, considered the most important creator of poetic drama. But the Irish Drama that really made the Abbey Theatre and the Irish Dramatic Movement effective was essentially a folk art which combined realism of environment and character "portrayal with the poetic colloquial dialogue; and temperament of Ireland. It is true that the Irish drama suffered considerable limitation because many of its writers turned their backs on Ibsen and the drama of ideas. Yet Lady Augusta Gregory's formula, taken from Aristotle, "To think like a wise man but express oneself like the common people" was sufficient to produce work of more than provincial distinction. Although Lady Gregory herself did not contribute profoundly, she brought peasant drama to the Abbey between 1906 and 1907 with one-a.ct plays.

'The Rising of the Moon' is a political one-act play. In this play, a police sergeant refrains from arresting a rebel who carries a tempting price on his head. The play takes place in a seaport town, during the night. It is a beautiful night and there is moonlight. There are three policeman, one of then is the sergeant. We learn from their talk that they are looking for a rebel who has managed to run away from gaol. They put up a notice describing the man. The Government has offered a hundred pounds for him. But the policemen believe that any of them who gets the man will be promoted:

Policeman B : A hundred pounds is little enough for the Goverment to offer for him. You may be sure any man in the force that takes him will get promotion.

We also understand that they are not so eager to find the man. But they feel that they have to do their duyt:

Policeman-X : And if we got him itself, nothing but abuse on our heads for it from the people, and maybe from our own relations.

Sergeant : Well, we have to do our duty in the force. Haven't we the whole country depending an us to keep law and order? 7

They are in a conflict. They have to do their duty but they also feel sympathy for the rebel. A ragged man appears when the sergeant

7 Gregory, Seven Short Plays (Dublin: 1940), p. 78. 
is alone. He says he is a ballad-singer. They talk about the rebel and the ragged man makes the sergeant remember the time when he was young:

Man

: And maybe the man you are watching for tonight used to be sitting on the wall, when he was young, and singing those same songs:. . It is' a queer world.

And isn't it a queer world?

Maybe it's one of the boys you used to be singing with that time you will be arresting to-day or to-morrow, and sending into the dock...8

Finally, it comes out that the man is the one they have been looking for. But the sergeant does not betray him and lets him go.

Man

: Well, good-night, comrade, and thank you. You did me a good turn to-night, and I'm obliged to you. Maybe I:11 be able to do as much for you when we all change places at the Rising of the Moon. ${ }^{9}$

The lesson taught by Lady Gregory could be easily absorbed, and to her influence may be traced much of the drama of the Irish stage. During the years when genius did not appear on the Abbey Stage it was good to have such plays, much better than the artificial ones so often favoured in London. Lady Gregory's dream was not her own but that of her fellow creators of Ireland. And Lady Gregory's example.resulted in a deluge of peasant drama and most important of all, the local-colour movement brought forth the genius of John Millington Synge.

Synge left a legacy in his important work that helped to sustain for decades Ireland's claim to an important place in the twentieth -century drama. Although each of Synge's six plays is memorable, The Playboy of the Western World is onc of the must important two plays. In the preface to this play he declares that all art was a collaboration and he had found the best collaborators in his simple

8 Ibid., p. 86.

9 İbid., p. 91. 
neighbours. He also said that on stage there should be reality and joy. Although he was against 'photographic reality' on stage, he was aware of the problems of life. He tried to escape from them in a back-to-nature romantic spirit. However, he was not a worshipper of the primitive.

He took note of the instability of the common man's affections in The Playboy of the Western World. As he had often done before, Synge took his subject-matter from an actual.occurrence recorded in his travel-sketches in The lsland. The background of the play is a small wayside public house on the wild coast of Mayo. The Landlord, Michael James Flaherty, is preparing to join in a wake at midinght, leaving his daughter, Margaret Flaherty (called Pegeen Mike), alone in the house. Shawn Keogh, a young farmer who is Pegeen's cousin comes in. He is an admirer of the girl and wants to marry her. But he is so much in awe of father Reilly, in other words the church, that he does not dare spend a night alone with his future wife. So, when a stranger appears on the scene she is ready to transfer her affections to him. The visitor, Christy Mahon, confesses that he has murdered his father:

Christy : Don't strike me. I killed my poor father, Tuesday was a week, for doing the like of that. ${ }^{10}$

After his confession, he becomes an interesting figure to Pegeen and the others. Hunted by the police, he has now taken refuge in the public-house. His fanciful story immediately makes him a popular hero. At the end of the first act, he is feeling very pleased with himself. During the following act, Christy is still the star. Every girl in the neighbourhood is in love with him. He tells his story over and over again, adding exciting details each time. Unfortunately, his father appears upon the scene aud Christy runs away. The lovesick widow helps him and wants to marry him. Christy tells her that he is in love with Pegeen. The widow offers to help him to win Pegeen. Christy is seen at the beginning of the third act as winner of the races on the beach. Now he is "the champion Playboy of the West". He has also won the love of Pegeen. But the "dead" Mahon arrives on the scene again. Christy attempts to kill him to regain his former prestige but he fails and this time his act is considered a repulsive crime, even by Pegeen. People are abcut to kill the boy when his

10 Synge, The Complete Plays (London: 1981), p. 183. 
father saves him. The father and the son leave the angry villargers, and Pegeen mourns over her disillusionment:

Pegeen : Ouit my sight. Oh, . my grief, I've lost the only Playboy of the Western World.11

Through his mock-hero Christy, Synge achieves the most precise exaggeration. Christy is a wonder to the people of Mayo and he talks himself into a wonder of his own imagination. The people who turn him into a hero suspend their moral judtement for the sake of a fine story, the story of a young man who has killed his father, the story of a "brave" act. It is the disguised comedy and the irony that gives the play its quality. It can be said that the comedy is directed against the people of Mayo and also against the artist whose love of fine words is dangerous. The love of fine words for their own sake, symbolized in Christy is a form of the search for something ethereal and refined.

After Synge, for fifteen years, the Abbey Theatre lacked a playwright of major standing, until it presented O'Casey's Juno and the Paycock in 1924. This play is, in the opinion of many, the best product of Sean O'Gasey's fusion of realism and poetry, of somber tragedy and comedy. The play place in the apartment of the Boyle family in Dublin. We have Jack Boyle, who is called "Captain", his wife Juno, their children Mary and Johny as the most important figures. They are rather poor but Jack does not like working. Johny is a desperate figure: he has lost his arm duing the Easter rebellion. He thinks he has done all he can for Ireland. The family rejoices at learning from Charles Bentham that Jack Boyle has inherited a a. fortune. Mary falls in love with him and gives up her former intended, Jerry Nevine. But things turn out to be unhappy when they find out that they cannot, in fact, have the money. Another misfortune is Mary's beina pregnant by Bentham. Johny is killed by two rebels who say that he has betrayed them. Their dream comes to an end; everything is worse than before. As Jack Boyle puts it, the whole world is in a terrible state of chaos. The language of the play is very powerful. The speech in which Mrs. Boyle requests Christ's compassion is memorable:

Mrs. Boyle $\quad: \ldots \ldots$ Mother o' God, have pity on us all! Blessed Virgin, where were you when me darlin'

11 İbid., p. 229. 
son was riddled with bullets, when me darlin' son was riddled with bullets? Sacred heart of jesus, take away our hearts o' stone, and give us hearts o' flesh! Take away this murderin', hate, an' give us Thine ovm eternal love!12

As we have discussed, one of the most remarkable developments of the modern theatre was the rise of the Irish Drama. Ireland made no contribution to the stage in modern limes until the last decade of the nineteenth century. 'Then it roused itself in response to nationalistic urges and gave the world the Abbey Theatre. Ireland's contribution was as timely as it was praiseworthy. The romantic revolt against Realism was beginning to lose its vitality. The Irish playwrights had the opportunity to give new life to drama by combining romanticism and realism. William Butler Yeats's contribution lies in his successful efforts as one of the creators of poetic drama. One of the new writers, J. M. Synge was a superb artist who acquired extreme sensitivity to the nuances of common life and most of his work provided a fusion of reality and imagination. While it was Lady Gregory who had brought peasant drama and local-colour to the stage, Synge was the artist who turned peasant drama into universal drama.

He proved that there is an English-language literature that is essentially Irish. The Irish Drarnatic movement alos produced a dramatist of first rank after the First World War, scmething that cannot be actually said for England. Sean O'Casey's powerful artistry linked him with the first period of the Abbey and he proved himself capable of turning common life into poetry. But it was with a new realism that he made an important contribution to Irish, English as well as to world drama. He introduced a critical spirit, and an awareness of twentieth century conflicts into the poetry of speech and mood already present in the Irish drama. This was important not only for Ireland but for the rest of the English speaking world.

The whole story of the collaboration between Yeats, Synge and Lady Gregory, with their prose writings, seems to be one of the most instructive events in recent literary history. They made the literary world more aware of the difficulties of planning a literary renaissance and of the organic complexity of a flourishing dramatic tradition.

12 Sean O'Casey, Three Plays: Juno and the Paycock, The Shadow of a Gunman, The Plough and the Star (London: 1930), p. 72. 